\title{
Peran Agama Sebagai Sarana Mengatasi Frustasi dan Depresi: Sebuah Telaah Psikologis
}

\begin{abstract}
Aris Saefulloh"
"Penulis adalah dosen tetap AA/N Sultan Amai Gorontalo Fakultas Ushuluddin dan Dakwah. Sejak Februari 2006 hingga kini, aliberi amanah sebagai sekretarisjun usan Komunikasi Penyiaran Islam (KPI) Fakultas Ushuludalin dan Dakwah.

Abstract: For religious people, the existence of a religion will affect the deepest side of them. Through deep understanding, a religion will guide them to find the solutions of any problem. The complexty of civilzation has led to the complicated problems they faced. In reality, religion shows itself in many kinds of realifies such as moral teachings, agidah, belief, and movement, which hove represented problems and social need of human beings. In fact, religion has a role in giving solutions to spiitual problems. This article tries to explain how a religion takes role and functions in human life from a psychological point of view. Keywords; religion, frustation, and Psychology.
\end{abstract}

\section{PENDAHULUAN}

Agama bagi sebagian besar orang menjadi kebutuhan yang paling esensial di antara kebutuhan-kebutuhan lainnya karena agama adalah kebutuhan mendasar dari manusia yang menginginkan kedamaian dan kebahagiaan. Agama memiliki peranan vital dalam kehidupan manusia, mengatur tatanan kehidupan secara pribadi sekaligus memberikan kontribusi yang sangat meyakinkan bagi kehidupan dan tatanan struktur sosial kemasyarakat. Dilihat dari perannya, maka agama mengatur pemeluknya untuk senantiasa berada dalam rel-rel yang telah ditentukan. Sementara itu, aturan yang terdapat dalam agama (Islam) mencakup seluruh aspek kebutuhan manusia, baik manusia sebagai makhluk individu dengan bebagai kebutuhan dan egonya, maupun manusia sebagai makhluk sosial yang senantiasa berhubungan dengan orang lain. Keyakinan terhadap agama memberikan efek bagi setiap individu karena agama mampu menggairahkan semangat hidup seseorang, meluaskan kepribadian, memperbarui daya hidup, serta mampu memberikan makna dan kemuliaan baru pada hal-hal yang biasa dalam kehidupan.

C.G. Jung, seorang psikiater Swiss mengungkapkan bahwa agama adalah jalan menuju keutuhan. ${ }^{1}$ Dengan demikian, tidak ada jalan lain untuk mencapai kesempurnaan pada diri seseorang sebelum ia meyakini dan menjalankan ajaran agama yang diyakininya. Ia berpendapat bahwa kita akan menemukan kualitas jiwa keagamaan yang maksimal, manakala kita melakukan aktualisasi diri atau ritual-ritual keagamaan secara mandiri (dengan khusu'), dan tidak akan diperoleh hanya dengan mengikut ritual-ritual keagamaan secara kolektif.

Agama bagi Jung didefinisikan sebagai keterkaitan antara kesadaran dan proses psikis tidak sadar yang memiliki kehidupan tersendiri. ${ }^{2}$ Dengan demikian, agama baginya sangat berperan positif dalam penyembuhan dan pengembangan psikologis manusia. Agama sangat membantu seseorang dalam menemukan jati diri atau pribadinya, the self. Proses dan perkembangan untuk menemukan jati diri itulah yang disebut dengan individuasi. Ia menyebutkan bahwa ada empat arketip paling mendasaryang menunjukkan kejiwaan seseorang yang paling mendasar, yaitu persona, animus, anima, dan shadow.

Persona seseorang akan menutupi ego dan kekurangan seseorang sehingga yang tampak adalah "penampakan" yang terbaik. Hal ini biasanya berkaitan dengan kebiasaan-kebiasaan "buruk" dalam pandangan orang banyak, namun dimiliki seseorang sehingga persona ini merupakan penampakan image baik di hadapan orang lain. Misalnya, bagaimana seseorang tahu diri untuk menahan buang angin, tatkala sedang berkumpul dengan teman-teman. 
Sementara animus dan anima dipandang sebagai aspek kejiwaan yang paling penting dari sudut pandang klinis. Animus merupakan aspek kelaki-lakian yang terdapat pada diri seorang wanita, sedangkan anima merupakan aspek kewanitaan yang ada pada diri laki-laki. Masing-masing termasuk pula cara masing-masing merasakan, menilai, membuat konsep, dan berhubungan. Baik animus maupun anima berperan membimbing kejiwaan seseorang saat berinteraksi gejolak kejiwaan satu dengan yang lainnya.

Shadow adalah bagian yang ada pada diri seseorang, namun di luar kesadarannya, terutama bagian yang tidak sama dengan citra diri seseorang, dan karena itu ditekan ke dalam jiwa tak sadarnya, depresi. Kecenderungan yang bersifat merugikan, "negatif", maka shadow sering bermunculan sebagai sosok yang mengerikan. Pengalaman-pengalaman seseorang yang berkaitan dengan shadow ini sangat membantu perkembangan spiritual seseorang (bertahap), bahkan sering terjadi "balik arah", konversi secara instan.

Agama memiliki peran signifikan yang turut memberikan sumbangsih bahkan mewarnai empat arketip mendasar tersebut agar menjadi sebuah nilai yang bermakna dalam kehidupannya, termasuk memberikan sumbangan dalam mengatur seseorang secara psikologis dalam meredam permasalahan-permasalahan (psikologis) yang dialami setiap orang. Siapapun dan di manapun, kehidupan seseorang "pasti" pernah mengalami problem-problem kehidupan, dengan tingkat permasalahan yang beragam. Problem dan permasalahan seseorang yang berkelanjutan, disadari maupun tidak dapat memicu munculnya frustasi dan/atau depresi. Di sinilah agama memiliki peran yang penting bagi "pengamanan” jiwa seseorang dari terjangkitnya frustasi atau depresi.

\section{HAKIKAT DAN SUBSTANSI AGAMA}

Kata "agama" merupakan salah satu kata yang menarik perhatian dunia pengetahuan. Dalam kenyataannya, makna agama terkadang menimbulkan kontroversi yang tidak jarang efeknya lebih besar dibandingkan arti penting permasalahannya. Hal ini tidak lepas dari pemahaman, sudut pandang, serta penempatan yang berbeda tentang makna agama. Faktor lain adalah terdapatnya beberapa kepercayaan yang diyakini sebagai agama, di samping tidakjelasnya batasanbatasan yang jelas memperlakukan agama dalam kajian sehari-hari menjadikan semakin mempersulit untuk mendefinisikan agama. Walaupun demikian, bukan berarti karena sulitnya untuk mendefinisikan tentang agama tersebut, maka agama menjadi kabur maknanya. Sekali lagi, ini disebabkan oleh pemahaman dan sudut pandang yang berbeda dalam memaknai agama. Lihat saja pendapat-pendapat bombastis tentang agama. Karl Marx mengatakan bahwa agama adalah candu bagi masyarakat. Banyak yang "berontak" dengan pernyataan Marx ini. Namun, bila dilihat dari latar belakang pemikirannya, maka dapat "dipahami” karena sebagai orang yang bebas nilai, Marx menganggap agama membatasi diri manusia dalam berekspresi dan berperilaku sebebas-bebasnya. Orang yang beragama hidupnya akan dibebani dengan ibadat, ke gereja, ke masjid dan sebagainya. Ritual-ritual semacam itu tidak ada dalam "kamus" Marx.

Apabila kita mengikut dengan pendapat Hegel yang mengatakan bahwa agama adalah pengetahuan yang dimiliki oleh akal terbatas. Pemahaman ini akan membawa pengertian bahwa agama yang diyakini oleh manusia sebagai produk pemikiran dalam pengertian yang amat sempit. Dengan demikian, agama hanyalah produk hasil pemikiran atau perenungan manusia (karya ilmiah) saja. Bila pendapat Hegel ini dianut secara radikal, maka seseorang akan dengan sangat mudah mendeklarasikan agama, bahkan akan berimbas pada mudahnya seseorang mendeklarasikan dirinya sebagai Nabi bahkan Tuhan.

Banyaknya pendapat mengenai agama dalam pandangannya masing-masing yang semata-mata terbatasnya pengetahuan dan pengalaman tentang keagamaan. Bagaimana seseorang dapat mengungkapkan definisi tentang agama bila dia sendiri tidak pernah mempunyai pengalaman tentang keagamaan. Tidak jarang agama dipahami dari pendekatan "kirakira". Hal ini tidak dapat semata-mata disalahkan karena memang agama itu sendiri mempunyai peran yang amat kompleks bagi tiap individu bahkan antarmasyarakat sehingga menimbulkan banyak persepsi. Kadang kala agama diterjemahkan sebagai salah satu cara untuk bertingkah-laku atau dimaknai sebagai aturan untuk hidup, dipahami dalam pengertian sebagai 
sistem kepercayaan, mungkin juga ditempatkan sebagai penghubung spiritual, atau juga agama adalah emosi yang bercorak, dan sebagainya.

Salah satu ciri khas dari agama adalah pengakuan dan keyakinan seseorang terhadap adanya Sang Khaliq tentang keberadaan alam semesta ini, yang disebut Tuhan. Setiap agama meyakini adanya Tuhan yang memiliki kekuasaan dan mengatur setiap gerak aksesoris alam. Keyakinan yang mendalam terhadap keberadaan Tuhan akan melahirkan pikiran, sikap, dan perilaku yang tercermin pada nilai-nilai ke-Tuhan-an yang diyakininya. Jangankan yang berbeda agama, bagi yang seagama saja terdapat perbedaan satu dengan yang lainnya. Semakin dalam pemahaman dan keyakinannya terhadap Tuhan, maka akan semakin tinggi kualitas dan kuantitas ritual keagamaan yang dilakukannya. ${ }^{3}$

Adapun beberapa definisi agama menurut berbagai tokoh atau ilmuwan antara lain sebagaimana akan disebutkan di bawah ini. James Martinean mendefiniskan agama sebagai kepercayaan kepada Tuhan yang selalu hidup, yakni kepada Jiwa dan kehendak Illahi yang mengatur alam semesta dan mempunyai hubungan moral dengan umat manusia.

Sementara itu, Herbert Spencer mengungkapkan bahwa agama adalah pengakuan bahwa segala sesuatu adalah manifestasi dari kuasa yang melampaui pengetahuan kita. Kemudian J.G. Fraizier mengungkapkan bahwa agama dimaksudkan sebagai upaya menyenangkan atau berdamai dengan kuasa-kuasa di atas manusia yang dipercayai dapat mengarahkan dan mengendalikan jalannya alam dan kehidupan manusia. F.H. Bradley menungkapkan bahwa agama hanyalah upaya mengungkapkan realitas sempurna tentang kebaikan melalui setiap aspek wujud kita. Lalu Mathew Arnold dengan ramah mengungkapkan bahwa agama adalah etika yang ditingkatkan, dinyalakan, dan diterangi oleh perasaan. J.M.I McTaggard secara pribadi mengungkapkan baginya bahwa agama yang paling baik digambarkan sebagai emosi yang didasarkan pada keyakinan akan harmoni di antara diri kita dan alam semesta secara keseluruhan.

Dengan nada lain C.P. Tiele mengungkapkan bahwa pada hakikatnya agama adalah disposisi atau kerangka pikir yang murni dan luhur yang kita sebut sebagai kesalehan.

Edward Caird mengungkapkan bahwa agama yang dimiliki oleh seseorang adalah ungkapan dari sikap akhirnya pada alam semesta, makna, dan tujuan singkat dari seluruh kesadarannya pada segala sesuatu.

Vergilius Fern mengungkapkan bahwa beragama berarti melakukan dengan cara tertentu dan sampai tingkat tertentu penyesuaian vital (betapapun tentatif dan tidak lengkap) pada apapun yang ditanggapi atau yang secara implisit atau eksplisit dianggap layak diperhatikan secara serius dan sunggung-sungguh.

Jika Freud menganggap agama adalah ilusi, maka sebaliknya dengan C.G. Jung yang memandang bahwa agama adalah jalan menuju keutuhan. Jung mendefinisikan agama sebagai keterkaitan antara kesadaran dan proses psikis tidak sadar yang mempunyai kehidupan tersendiri. Agama adalah pertimbangan dan pengamatan yang cermat pada faktor dinamis, kekuasaan, pada tenaga-tenaga tidak sadar, dan pada simbol-simbol yang mengungkapkan kehidupan tenaga-tenaga ini, pada yang batiniah, yakni gerakan dinamis di luar kendali kesadaran.

Senada dengan Jung, William James mengatakan bahwa agama sebagai jalan menuju keunggulan manusia. Sementara itu, Robert $\mathrm{H}$. Thouless mengatakan bahwa agama adalah hubungan praktis yang dirasakan dengan apa yang dipercayai sebagai makhluk atau wujud yang lebih tinggi daripada manusia.

\section{AGAMA DAN KEBUTUHAN MANUSIA}

Agama sebagaimana yang kita pahami, kini semakin mendapatkan tempat dalam berbagai kajian, baik yang memang khusus berkaitan dengan agama maupun kajian-kajian lain (umum/praktis) yang dengan sengaja atau tidak menyentuh agama dalam rasio berpikirnya. Hal ini tidak lepas dari keyakinan bahwa agama merupakan bagian dari kebutuhan seseorang yang tidak dapat dilepaskan secara individu/pribadi maupun dalam tatanan sosial kemasyarakatan. Dilihat dari sisi perilakunya, agama telah menunjukkan dan menopang gejala perilaku psikologis seseorang.

Seseorang akan merasa tidak tenang manakala kondisi kejiwaannya mengalami kegoncangan. Harun Yahya meyakini bahwa ketidakyamanan kejiwaan dan kekhawatiran disebabkan oleh keengganannya terhadap agama.4 Dalam pandangan lainnya, kegoncangan tersebut tidak lebih disebabkan oleh tidak terpenuhinya kebutuhan-kebutuhan (mendasar) seseorang, 


\section{JURNAL DAKWAH DAN KOMUNIKASI}

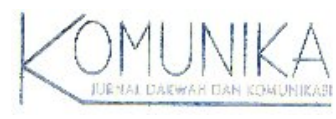

yang meliputi kebutuhan jasmani, ruhani, dan sosial. Sementara itu, untuk memperbincangkan kebutuhan manusia berarti membicarakan kebutuhan kita sendiri. Walaupun diakui bahwa kebutuhan manusia satu dengan yang lainnya tidak selamanya berbeda. Terlebih bila kebutuhan tersebut sudah bersentuhan dengan rasa, maka akan sangat berbeda satu dengan yang lain, dikarenakan setiap orang sangat rentan dan sensitif dalam menghadapi problem dan permasalahannya.

George J. Mouly (1873) mengungkapkan bahwa sesungguhnya secara umum manusia memiliki dua kebutuhan yang ingin dan harus dipenuhinya, yaitu (1) kebutuhan fisiologis, yaitu kebutuhan makanan, kebutuhan air, tidur, istirahat, dan seks; (2) kebutuhan psikologis, yaitu kebutuhan yang meliputi kasih-sayang, rasa memiliki, berprestasi, mandiri, pengakuan sosial, kebutuhan harga diri, dan sebagainya.

Adapula klasifikasi kebutuhan manusia sebagaimana Maslow dengan teorinya mengungkapkan bahwa kebutuhan manusia adalah sebagai berikut.

\section{Aktualisasi Diri}

(memaksimalkan potensi)

Penghargaam (merasa berguna)

Sosial (pergaulan, cinta, dll.)

Rasa Amam (bebas dari rasa takut, pekerjaan mapan, dll.)

Fisiologi (kelangsungan hidup: makan, sandang, papan, seks, dll.)

Kebutuhan sebagaimana teori Maslow tersebut menunjukkan bahwa mengalami perkembangan seiring dengan perkembangan kejiwaannya. Awalnya seseorang hanya membutuhkan bagaimana caranya memenuhi kebutuhan-kebutuhan fisiologi, bagaimana dapat makan, sandang, papan, seks dan sejenisnya. Bila sudah terpenuhi kebutuhan fisiologinya, maka dipastikan akan beranjak bagaimana rasa aman itu terpenuhi sebagai sebuah kebutuhan, lalu kebutuhan sosial, dan seterusnya. Coba renungkan di mana letak agama ditempatkan sebagai kebutuhan!

Di sisi lain, Zakiyah Daradjat mengungkapkan bahwa kebutuhan manusia terbagi atas dua kebutuhan secara umum, yaitu kebutuhan primer dan kebutuhan sekunder. ${ }^{5}$ Kebutuhan primer adalah kebutuhan yang dirasakan oleh jasmani yang dibutuhkan dan didapat oleh manusia secara fitrah tanpa dipelajari, seperti kebutuhan sandang, pangan, papan, seks, kebutuhan perlindungan diri, rasa ingin tahu, rasa humor, dan sebagainya. Sementara itu, kebutuhan sekunder adalah kebutuhan ruhaniah, jiwa dan sosial. Kebutuhan skunderyang pokok, terbagi menjadi 6 kelompok;

1. kebutuhan pada rasa kasih sayang;

2. kebutuhan pada rasa aman;

3. kebutuhan pada rasa harga diri;

4. kebutuhan pada rasa bebas;

5. kebutuhan pada rasa sukses;

6. kebutuhan rasa ingin tahu.

Di samping kebutuhan yang bersifat individual tersebut, dalam realisasinya terdapat juga kebutuhan manusia yang bersifat sosial. Kebutuhan ini merupakan kebutuhan yang dipengaruhi atau datang dari luar sebagai stimulus. Kebutuhan ini menurut Guilford, antara lain:

1. pujian dan hinaan;

2. kekuasaan dan mengalah;

3. pergaulan;

4. imitasi dan simpat;

5. perhatian

Kebutuhan-kebutuhan sosial tersebut dalam kehidupan bermasyarakat membentuk dan berbentuk nilai. Nilai-nilai tersebut bukanlah berbentuk kebutuhan biologis, melainkan kebutuhan-kebutuhan yang bersifat kejiwaan (ruhani). Manusia 
yang tidak dapat melepaskan diri dari kehidupan sosial tersebut, mau tidak mau membutuhkan agama dalam rangka bersinergi dengan nilai-nilai sosial yang ada. Inilah mengapa manusia disebut sebagai homo religious sehingga manusia yang dibekali kekuatan berpikir dan daya analisis, diberi pula rasa bingung dan kebimbangan untuk memahami dan belajar mengenali alam sekitarnya. Hal inilah yang mendorong jiwa keagamaan muncul dalam diri seseorang karena dia akan terangsang untuk mencari kekuatan yang dapat membimbing kejiwaannya, Tuhan, akhirnya ditemukan.

Yang kemudian menjadi permasalahan manakala serentetan kebutuhan tersebut tidak dapat dipenuhi oleh seseorang. Ia dipastikan akan berusaha untuk dapat menyesuaikan diri agar dapat dengan cepat memenuhi asa yang diinginkannya. Tidak terpenuhinya kebutuhan-kebutuhan manusia tersebut akan memicu lahirnya problem-problem kehidupan, artinya bahwa problem dan permasalahan yang dihadapi seseorang amat universal, termasuk agama yang sudah menjadi pedoman kehidupan seorang muslim.

\section{AGAMA SEBAGAI SARANA MENGATASI FRUSTASI}

"Kemudian apabila kamu telah membulatkan tekad, maka bertawakallah kepada Allah. Sesungguhnya Allah menyukai orang-orang yang bertawakkal kepada-Nya”(Q.S.Ali Imran: 159).

Setiap orang dalam kehidupannya pasti pernah memiliki problem yang dialaminya. Problem dihadapi oleh masingmasing tersebut amat bervariasi, dan biasanya tidak bisa terlepas dari pemenuhan kebutuhan (baik jasmani maupun ruhani) dari masing-masing individu. Setiap orang memiliki keinginan untuk dapat mencukupi kebutuhan (jasmaninya) secara mudah. Berbagai jalan dan usaha dilakukan untuk dapat memenuhi kebutuhannya tersebut. Tidak jarang, walaupun sudah dengan berbagai upaya, tetapi usahanya tersebut belum dapat mewujudkan apa yang dïnginkannya. Kelelahan, kekesalan, kejenuhan, rasa putus-asa, gundah, dan sebagainya pun bercampur menjadi satu. Semuanya terasa amat sulit, terlebih bila dibarengi dengan problem-problem lain, seperti anak nakal, tidak mudah diatur, senantiasa bikin ulah di sekolah, sementara sang istri menuntut berbagai macam kebutuhan rumah tangga, tempat beras yang sudah kosong, minyak yang sudah habis, dan sebagainya. Kesemuanya sangat mendukung seseorang mengalami stres, frustasi, bahkan dapat mengakibatkan depresi dan gangguan jiwa.

Stres dan depresi yang dianggap sebagai penyakit di zaman kita, tidak hanya berbahaya secara kejiwaan, tetapi juga mewujud dalam berbagai kerusakan tubuh. Gangguan umum yang terkait dengan stres dan depresi adalah beberapa bentuk penyakit kejiwaan, ketergantungan pada obat terlarang, gangguan tidur, gangguan pada kulit, perut dan tekanan darah. Tentu saja stres dan depresi bukanlah satu-satunya penyebab semua ini, namun secara ilmiah telah dibuktikan bahwa penyebab gangguan kesehatan semacam itu biasanya bersifat kejiwaan. ${ }^{6}$

Masih segar dalam ingatan kita, ada beberapa ibu rumah tangga yang tega membunuh (seluruh) anaknya, dengan alasan karena kurangnya pemenuhan kebutuhan ekonomi keluarga, atau adanya ketakutan tidak dapat memenuhi kebutuhan anakanaknya. Dalam tingkatan tersebut, seseorang sudah mengalami frustasi dan depresi yang mengarah kepada gangguan kejiwaan.

Di sisi lain, tidak jarang juga orang yang merasa hampa dengan kehidupannya, padahal ia memiliki harta yang melimpah. Memiliki beberapa rumah mewah, dengan halaman luas, mobilnya banyak hingga garasinya tidak muat untuk menyimpan mobil mewahnya. Namun, di balik serba kemewahan tersebut, banyak di antara mereka yang merasa kehampaan dalam hidupnya. Bapaknya sibuk dengan urusan bisnis, ibunya sibuk dengan arisan dan kegiatan sosial. Sementara itu, sang anak sibuk sendiri dengan urusan muda-mudi. Semua anggota keluarga sibuk dengan urusan dan kegiatan masingmasing, di antara anggota keluarga jarang saling bertemu, berkumpul, apalagi bersenda-gurau di antara mereka. Suasana ini sering dijumpai dalam kehidupan bermasyarakat, dan apabila kita penggemar sinetron, maka hal itu adalah bukan kondisi yang asing. Hal ini merupakan gambaran sebagian kelompok masyarakat di Indonesia.

Kesibukan masing-masing pribadi anggota keluarga menjadikan kehidupan dalam keluarga kehilangan ruh dan hampa. Kurangnya perhatian orangtua kepada anak merupakan embrio adanya perilaku menyimpang yang dilakukan anak, dan ini tidak jarang menjadi pemicu konflik keluarga (suami-istri), saling menyalahkan. Akan menjadi parah manakala ditambah 
dengan adanya problem pekerjaan, yang menambah runyam keguncangan jiwanya. Dalam kondisi inilah, peran agama sangat terasa membantu dalam menentramkan kejiwaannya. Dengan landasan agama, wudlu akan menyirami kepenatannya, shalat akan meredam emosinya, alunan ayat-ayat al-Qur'an akan membendung amarahnya. Keihlasan menjadi acuan tingkah-lakunya, dan sabar menjadi pegangan dalam menghadapi problem dan permasalahannya. Sungguh terasa amat sejuk, damai, dan nyaman setelah mengenal dengan mendalam mukjizat ajaran Islam.

Terlihat agama mampu meredam gejolak problem kejiwaan dan berperan sebagai sarana untuk mengatasi frustasi yang dialami seseorang. Agama memang ada yang menyebutkan berasal dari bahasa Sanksekerta, a yang artinya tidak, dan gama yang artinya kacau. Dengan demikian, agama dengan menggabungkan dua kata tersebut dimaknai sebagai tidak kacau, artinya bahwa agama berfungsi untuk memelihara integritas dari seseorang atau sekelompok orang agar hubungannya dengan sesama, Tuhan, dan alam sekitarnya menjadi tidak kacau. Pengertian ini juga dapat diambil dari bahasa Inggris, religius, yang berasal dari bahasa Latin, religio yang berakar pada kata religare, yang berarti mengikat. Dalam pengertian ini, religio memuat aturan tentang kebaktian bagaimana manusia mengutuhkan hubungannya dengan realitas tertinggi (hablun mina Allah) dalam penyembahan dan hubungannya dengan sesama (hablun mina annas). Religare juga mengandung makna melihat kembali ke belakang kepada hal-hal yang berkaitan dengan perbuatan Tuhan yang harus diresponnya agar menjadi pedoman atau panduan dalam hidupnya.

Keengganan orang-orang yang jauh dari agama untuk taat kepada Allah menyebabkan mereka terus-menerus menderita perasaan tidak nyaman, khawatir, dan stres. Akibatnya, mereka terkena berbagai macam penyakit kejiwaan yang mewujud pada keadaan raga mereka. Tubuh mereka lebih cepat mengalami kerusakan, dan mereka mengalami penuaan yang cepat dan lemah. Ketika seseorang menderita stres, tubuhnya bereaksi dan membangkitkan tanda bahaya sehingga memicu terjadinya beragam reaksi biokimia dalam tubuh. Kadar adrenalin dalam aliran darah meningkat; penggunaan energi dan reaksi tubuh mencapai titik tertinggi; gula, kolesterol dan asam-asam lemak tersalurkan ke dalam aliran darah; tekanan darah meningkat dan denyutnya mengalami percepatan. Ketika glukosa tersalurkan ke otak, kadar kolesterol naik. Dalam rentang waktu lama berujung pada kemunculan dini gangguan-gangguan seperti diabetes, penyakit jantung, tekanan darah tinggi, kanker, penyakit pernafasan, dan eksim.?

Kondisi di atas dapat menimpa siapa saja, terutama bagi mereka yang tidak memiliki kedamaian rasa dalam dirinya. Dalam hal ini, semua pakar sepakat bahwa orang yang agresif, pemarah, tidaksabar, khawatir, cemas, dan mudah tersinggung akan memiliki berpeluang lebih besar terkena penyakit atau gangguan sebagaimana disebutkan di atas. Terlebih dalam kondisi dan perkembangan peradaban saat ini, yang sangat mudah memicu munculnya benih-benih gangguan tersebut.

...hingga apabila bumi telah menjadi sempit bagi mereka, padahal bumi itu luas danjïwa mereka pun telah sempit oleh mereka, serta mereka telahmengetahuibahwatidakada tempat lari dari (siksa) Allah, melainkan kepada-Nya saja ...8

Dan barang siapa berpaling dari peringatan-Ku, maka sesungguhnya baginya penghidupan yang sempit, dan Kami akan menghimpunkannya pada hari kiamat dalam keadaan buta...9

Petikan dua ayat di atas menunjukkan bahwa dengan beragama, seseorang akan terhindar dari kesempitan dan kegelapan (buta). Agama memang tidak memberikan pemenuhan kebutuhan secara jasmani, namun agama menawarkan kepuasan rasa (lewat syukur) dan kepasrahan terhadap segala apa yang terjadi. Dengan demikian, akan menciptakan kedamaian yang menghindarkan diri dari ketidaknyamanan, kekhawatiran, dan kegundahan jiwa. Intinya dalam kondisi apapun, agama dapat muncul sebagai jawaban atas segala problem manusia dan menjadi penampakan tertinggi yang secara misterius sangat membantu seseorang dalam menemukan kedamaian jiwanya, walaupun terkadang agama muncul sebagai sesuatu yang menakutkan di samping menjadi sesuatu yang memesonakan. Untuk mencapai kedamaian tersebut, seorang beragama tidak lantas berdiam diri dengan nilai yang didapatinya, namun ia harus merespon bahkan terdesak secara batiniah untuk merespon nilai-nilai tersebut. Merespon nilai-nilai keagamaan inilah yang nantinya akan bersentuhan dengan pokokpokok agama yang akan menjadikan tuntunan, baik dalam berpikir dan berperilaku yang secara realitanya mampu meredam gejala frustasi maupun depresi yang dialami seseorang. 


\section{JURNAL DAKWAH DAN KOMUNIKASI}

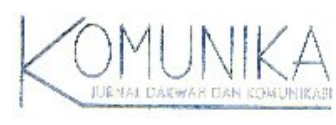

Secara lebih rinci lagi, nilai dan manfaat agama sebagai sarana mengatasi frustasi tergambar dalam beberapa pandangan sebagai berikut.

\section{Agama Menanamkan Rasa untuk Senantiasa Pasrah}

Pasrah atau tawakal dengan sepenuh hati atas usaha yang diinginkannya seraya menyandarkan kepercayaan kepada Allah yang menentukan dan memutuskan segala sesuatu yang ada, termasuk usaha yang dilakukannya. Walaupun menanamkan pasrah tidak berarti keinginan mencapai tujuan/keinginan tanpa usaha. Tawakal dan berdoa diikuti dengan usaha memiliki peran yang besar, khususnya dalam memacu semangat seeorang untuk mencapai usaha yang diinginkannya. Dari pengamatan psikologis, tawakal yang benar-benar dilakukan seseorang akan menjadi sarana yang paling efektif untuk menggapai tujuan yang dïnginkannya. Dengan tawakal yang dilakukan seseorang akan menyandarkan hasil usahanya pada kekuasaan yang maujud, di balik kekuasaan, kemurahan, dan kelembutan Allah SWT, di mana akan dikikis habis segala bentuk frustasi dan kemalasan.

Kemudian apabila kamu telah membulatkan tekad, maka bertawakallah kepada Allah. Sesungguhnya Allah menyukai orang-orang yang bertawakal kepada-Nya. ${ }^{\text {D }}$

\section{Tujuan Agama adalah Membawa Umatnya pada Kebahagiaan}

Semua pasti sepakat bahwa tidak ada agama yang bertujuan untuk menyengsarakan umatnya. Semua agama yang ada di dunia ini, memiliki tujuan yang sama, yakni untuk memuliakan umatnya. Dengan beragama, seseorang akan merasa mulia paling tidak di mata kelompoknya. Manakala seseorang yang senantiasa menyandarkan perbuatannya kepada Allah, maka nilai yang akan muncul adalah kemuliaan di mata Allah. Mereka yakin bahwa semakin kita berserah kepada Allah dan mengikuti setiap ajaran atau nilai yang diajarkan, maka kita akan semakin mulia. Dasar inilah yang menjadikan seseorang senantasa berlindung kepada Allah SWT. Dengan berserah diri itulah, keamanan dan kenyamanan akan dapat terwujud, hilangnya rasa takut dalam dirinya, selain takut kepada Allah. Apabila seseorang menyadari bahwa apa yang ditakdirkan mengenainya tidaklah akan meleset darinya, dan apa yang meleset ditakdirkan darinya tidaklah akan mengenainya, maka jiwanya akan tenang. Hasil ketenangan jiwa inilah yang kemudian melahirkan sikap untuk senantiasa menyerahkan segala sesuatu kepada Allah SWT, untuk menggapai kemuliaan sejati.

\section{Agama Senantiasa Senafas dengan Ilmu Pengetahuan}

Maka renungkanlah al-Qư’an itu dan carilah keagungan makna-maknanya, sehingga memungkinkan Anda meraih pertemuan ilmu-ilmu klasik dan ilmu-ilmu modern dan seluruh permulaan-permulaannya di dalamnya. Perenungan terhadap al-Quran ini dimaksudkan untuk mencapai penggambaran ringkas ilmu-ilmu tersebut, sampai pengetahuan yang terinci, dan inilaksana samuderayangtakbertepi."

Melalui al-Quran agama Islam memadukan insight (pengetahuan yang mendalam), ilmu pengetahuan, dan amal sosial dalam suatu formula untuk dipegang teguh oleh manusia. Artinya, Islam sangat mengedepankan ilmu pengetahuan dalam berinteraksi dan berkehidupan sosial. Dengan demikian, agama seharusnya tidak hanya menjadi sesuatu yang hanya dimanfaatkan untuk kepentingan manusia (something to use), tetapi lebih fungsional sebagai comprehensive commitment dan driving integrating motive yang mengatur seluruh hidup seseorang. .2 Dengan mengacu pada pernyataan tersebut, Islam tidak ada keraguan Islam yang senafas dengan peradaban. Perbedaan yang muncul dalam kehidupan masyarakat merupakan dinamisasi nilai-nilai keislaman yang saling mendukung dan saling melengkapi antara satu dengan yang lainnya.

Syariat Islam yang benar (sempurna dan universal) telah memerintahkan untuk mempelajari semua ilmu pengetahuan yang memiliki nilai manfaat. Hal ini membuktikan bahwa Islam menjunjung tinggi ilmu pengetahuan. Kini sudah banyak disiplin ilmu yang senafas dengan upaya-upaya untuk mewujudkan bahwa nilai-nilai Islam senantiasa senafas dengan perkembangan zaman.

\section{Agama Memadukan Kepentingan Manusia secara Utuh (Ruh, Hati, dan Tubuh)}


Ruh, hati, dan tubuh adalah organ-organ dan aspek atau aksesoris manusia yang tidak dapat dipisahkan. Ketiganya menyatu tidak dapat terpisahkan dan saling membutuhkan. Ketiga aksesoris tersebut merupakan aspek yang paling penting dan diunggulkan dari aspek lainnya, serta kepentingan yang satu tidak merampas kepentingan yang lain. Segala sesuatunya berjalan dengan sangat cermat, harmonis dan seimbang. Sebab jika salah satunya tidak mendukung kegiatan lainnya, maka tidak akan menciptakan hasil yang diinginkan. Walaupun Islam memberikan perhatian yang besar kepada aspek penyucian jiwa dan peningkatan ke derajat keberuntungan, namun ia tidak mengabaikan hak-hak indera (tubuh). Islam memberikan nuansa dan peran yang adil untuk setiap organ tubuh yang dimiliki.

Sebagai bukti bahwa Islam sangat menjunjung tinggi tiga aspek tersebut, antara lain adanya perintah untuk menjaga ruh dengan senantiasa menjalin komunikasi (itikaf, dzikir, shalat, atau ritual keagamaan lainnya) kepada Tuhannya. Di samping itu menyirami hati dengan pikiran, perilaku. serta amal yang positif sehingga kedamaian dan ketenangan hati akan tumbuh mekar dengan segar. Sementara itu, untuk menjaga kebugaran tubuh, Islam mengajarkan kita untuk memakan makanan yang halal, sehat, minuman yang baik, dan diperbolehkan mengeksplorasi alam dan lingkungan untuk "kesenangan" dirinya, sepanjang senafas dengan aturan agama.

\section{Agama Menjunjung Tinggi Akal Manusia}

Islam sangat menjunjung tinggi akal sehat, menghargai perannya, mengangkat kedudukannya, tidak mengekangnya, serta tidak mengingkari aktivitasnya. Dalam berbagai ayat al-Qur'an, Islam justru menantang akal untuk mengamati di balik keberadaan dunia, yang memberikan peluang seluas-luasnya kepada akal untuk "mengkritisi" segala ketetapan Tuhan berkaitan dengan alam semesta. Sesungguhnya tujuan tantangan kepada akal tersebut agar manusia dapat memahami ketetapan Ilahi dengan memberdayakan akal sebagai sarananya, di samping untuk mengetahui rahasia-rahasia alam semesta dan fakta-fakta kehidupan.

Islam meminta agar setiap insan mengamati langit dan bumi, merenungkan dirinya sendiri dan tanda-tanda kekuasan Allah SWT yang ada di sekitarnya. Dengan demikian, Islam adalah agama yang amat menghormati kedudukan dan peran akal manusia. Dalam suatu riwayat Islam memberikan kabar buruk bagi mereka yang tidak menggunakan akal, mereka melakukan "tradisi" apa yang dilakukan leluhurnya.

\section{Agama Mengakui Perasaan Manusiawi dan Mengarahkannya ke Arah yang Benar}

Perasaan adalah sesuatu yang bersifat naluri (insting), dan setiap manusia yang normal pasti memiliki perasaan. Islam bukanlah aqidah yang beku dan statis, melainkan aqidah yang hidup dan dinamis. Islam sangat mengakui perasaan manusiawi dan mengarahkannya kepada jalan yang benar sehingga mampu menjadi sarana untuk menuju kebaikan dan pengembangannya.

Melalui aqidah, agama Islam mengendalikan perasaan cinta, benci, dan perasaan lainnya yang perlu diproses untuk mendapatkan pertimbangan matang dari pemilik perasaan tersebut sehingga lahirlah sikap bijaksana, interaksi sosial yang tinggi, serta landasan yang kokoh dalam menentukan pilihan atas dasar pertimbangan-pertimbangan yang benar.

\section{Aqidah Islam Fleksibel dan Mampu Menjawab Segala Problem Kehidupan}

Islam diturunkan untuk memberikan rahmat bagi seluruh alam semesta, termasuk pula dalam menyelesaikan konflik dan problematika yang muncul dalam kehidupan bermasyarakat dan beragama. Melalui agama problem permasalahan seseorang dapat dipertemukan dalam penyatuan jiwa antar-pemeluknya.

\section{KESIMPULAN}

Sudah menjadi “sumnatullah" bahwa manusia diciptakan untuk berpikir, merasa, serta berkehendak sebagaimana yang dïnginkannya. Manusia dapat berperan sebagai subjek, namun dapat pula berperan sebagai objek bahkan kedua-duanya sekaligus. Apapun yang dilakukannya, "layak" untuk mendapat perhatian manusia lainnya. Apabila apa yang dilakukannya 
menarik perhatian manusia lainnya, kemudian dicoba hingga mengikuti perilaku yang dilakukannya adalah hal yang wajar dalam kehidupan manusia di dunia, walaupun itu boleh jadi bertentangan dengan manusia atau sekelompok manusia lainnya, masuk akal ataupun tidak. Termasuk di dalamnya, kehidupan beragama seorang manusia maupun sekelompok manusia. Perilaku agama adalah keyakinan yang "membumi" dari setiap individu manusia, "dilestarikan" (disiarkan) secara turun-temurun dari satu generasi ke generasi berikutnya sebagai nilai ibadah. ${ }^{13}$

Dalam pandangan psikologis, agama dimaknai dalam berbagai pengertian dan sudut pandang. Akal dan kebebasan berpikir yang dimiliki manusia menjadikan sudut pandang yang berbeda dalam memaknai agama sehingga tidak jarang agama menimbulkan makna sekaligus ritual yang beragam. Banyak faktor yang mempengaruhi perbedaan-perbedaan tersebut, mulai dari keyakinan, tradisi, lingkungan, bahasa, dan masih banyak lagi. Ada yang berpendapat bahwa pangkal agama terletak pada ritual ibadahnya, namun ada pula yang beranggapan bahwa agama terletak pada akhlak serta pengabdian kita kepada sesama manusia. Adapula yang bersikap "ekstrim" bahwa agama dimaknai dengan pengorbanan untuk suatu keyakinan, berlatih, dan mencari bekal untuk mati atau mencari mati (istyhad) demi keyakinan. Dari kondisi ini, maka menterjemahkan agama haruslah mampu pula melihat sudut pandang yang berbeda, yang mampu mewakili seluruh kelompoksudut pandangyang ada.

Seiring dengan perkembangan zaman, keberadaan agama memang tidak dapat dilepaskan dari kehidupan modern. Apapun alasan kebenciannya, betapapun ia tidak percaya kepada Tuhan, betapa pun ia bebas nilai, namun ia tidak dapat melepaskan diri dari kehidupan beragama. Oleh karena itulah kini permasalahan agama (Islam), tidak lepas dari incaran kajian-kajian keilmuan yang berkembang. Hingga lahirlah ekonomi Islam, politik Islam, filsafat Islam, sosiologi Islam, psikologi Islam, psikoterapi Islam, bahkan mulai muncul kedokteran ala Islam. Sementara itu, kajian yang dekat untuk mengetahui karakteristik dan perilaku kejiwaan adalah psikologi sehingga untuk mengetahui kejiwaan masalah keagamaan adalah psikologi agama, yang kini mulai mendapat sambutan hangat dari para ilmuwan, baik yang dirinya memang sudah berbasis agama, maupun yang secara murni ingin mengetahui (nonagama).

Bagi manusia beragama, keberadaan agama akan menyentuh bagian terdalam dari dirinya. Sementara itu, psikologi akan membantu seseorang dalam menghayati agamanya serta memahami penghayatan orang lain atas agama yang diyakininya, dan membantu kita dalam menemukan kunci-kunci penyelesaian permasalahan. Sebagaimana kita ketahui, kita amati, dan kita rasakan, kehadiran agama dalam kehidupan seseorang akan melahirkan atau menampakkan dirinya dalam bermacam-macam realitas, mulai dari ajaran moral, aqidah, kepercayaan, hingga ideologi gerakan. Ideologi gerakan biasanya merupakan penggabungan ekspresi diri untuk menghadirkan keyakinannya. Bentuknya sangatlah bermacam-macam, mulai dari kegiatan spiritual yang bersifat individu, hingga ekspresi massal yang melambangkan kekuatan agama yang diyakini secara bersama-sama. Semakin banyak massa yang mengikutinya mengindikasikan kebesaran dan kekuatan bahwa agama yang diikutinya juga diyakini banyak orang. Termasuk di dalamnya ritual-ritual keagamaan yang dilakukan secara individu maupun massal. Kondisi ini diakui atau tidak, sedikit menyulitkan untuk memahami agama secara ilmiah. Oleh karenanya sebagian definisi dan ritual keagamaan tidak komprehensif, dan hanya memuaskan pembuat atau pengikutnya.

\section{ENDNOTE}

${ }^{1}$ C.G. Jung. Psyche and Symbol (New York: Doubleday, 1958), hal. 117.

${ }^{2}$ Ibid.

${ }^{3}$ Dalam penelitian Duma Rachmat Artanto, proses tumbuhnya persepsi dan keyakinan terhadap Tuhan temyata dapat dipahami dan dapat dilakukan sedini mungkin. Duma Rachmat Artanto. Mah. .. Inikah Tuhan? Memahamkan Tuhan pada Anak. (Yoyakarta: Pinus, 2005).

${ }^{4}$ Harun Yahya, "Stres dan Depresi: Akibat Tidak Menjalankan Agama", dalam www.hanunyahya.com, diakses pada 25 Juni 2008.

${ }^{5}$ Zakiyah Daradjat, Peranan Agama dalam Kesehatan Mental (Jakarta: Gunung Agung, 1970).

${ }^{6}$ Harun Yahya. Stres dan Depresi.

${ }^{7}$ Ibid.

${ }^{8}$ Q.S. at-Taubah, 9: 118. 


\section{JURNAL DAKWAH DAN KOMUNIKASI}

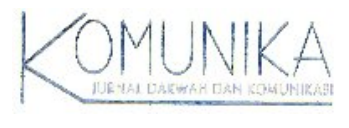

${ }^{9}$ Q.S. Thaha, [20]: 124.

${ }^{10}$ Q.S. ali-lmran: 159.

${ }^{11}$ Abu Hamid al-Ghazali, The Jewels of the Quran, Ter. Muhammad Abu al-Qasim (Routledge: Kegan Paul, 1983), hal. 45-48.

12 Jalaludin Rahmat, Islam Altematif (Bandung: Mizan, 1991).

${ }^{13}$ Ibadah adalah imbalan yang akan diterima seseorang dari Tuhan yang diyakininya, dan dapat diperoleh baik dalam kehidupannya di dunia maupun kehidupan setelah kehidupan di dunia (akhirat).

\section{DAFTAR PUSTAKA}

Al-Ghazali, Abu Hamid. 1983. The Jewels of the Quran. Ter. Muhammad Abu al-Qasim. Routledge: Kegan Paul. Artanto, Duma Rachmat. 2005. Mah. .. Inikah Tuhan? Memahamkan Tuhan pada Anak. Yoyakarta: Pinus. Daradjat, Zakiyah. 1970. Peranan Agama dalam Kesehatan Mental. Jakarta: Gunung Agung. Jalaludin. 2003. Psikologi Agama. Jakarta: PT.Raja Garfindo Perkasa. Jung, C.G. 1958. Psyche and Symbol. New York: Doubleday.

Rahmat, Jalaludin. 1991. Islam Attematif. Bandung: Mizan. 2005. Psikologi Agama Sebuah Pengantar. Bandung: Mizan.

Ramayulis. 2004. Psikologi Agama. Jakarta: Kalam Mulia.

Yahya, Harun. "Stres dan Depresi: Akibat Tidak Menjalankan Agama”, dalam www.harunyahya.com/indo diakses pada 25 Juni 2008. 